\title{
Response of Salt-Stressed Common Bean Plant Performances to Foliar Application of Phosphorus (MAP)
}

\author{
Mostafa M. Rady ${ }^{a}$, Ahmed A. El-Shewy, Mohamed A. Seif El-Yazal, \\ Kariman E.S. Abdelaal
}

\author{
Botany Department, Faculty of Agriculture, Fayoum University, Fayoum 63514, Egypt \\ Corresponding author e.mail: ${ }^{a} \mathrm{mmr02@fayoum.edu.eg}$
}

Keywords: Salinity, plant performance, photosynthesis, water relations.

\begin{abstract}
The study objective is to evaluate the effect of mono-ammonuim phosphate (MAP; 0, 10, and $20 \mathrm{mM}$ ) applied as foliar application on the growth traits, green and dry yields characteristics, leaf photosynthetic pigments, chlorophyll fluorescence, and leaf contents of nutrients of common bean (Phaseolus vulgaris L., cv. "Bronco") plants grown under saline soil conditions. To perform this objective, two field trials were conducted at the Experimental Farm of Faculty of Agriculture, Fayoum University during the 2016 and 2017 summer seasons. The obtained results showed that, $\mathrm{Na}^{+}$content was significantly declined, while the all other tested parameters such as growth characteristics (i.e., shoot length, number of leaves per plant, area of leaves per plant, and shoot fresh and dry weights), yield characteristics of green pods and dry seeds (i.e., average pod weight, number of pods per plant, pods weight per plant, dry seed weight per plant and 100-seed weight), leaf photosynthetic pigments (i.e., total chlorophylls, total carotenoids) contents and leaf chlorophyll fluorescence (i.e., Fv/Fm and PI), leaf contents of $\mathrm{N}, \mathrm{P}, \mathrm{K}^{+}$, and $\mathrm{Ca}^{2+}$, and the ratios of $\mathrm{K}^{+} / \mathrm{Na}^{+}, \mathrm{Ca}^{2+} / \mathrm{Na}^{+}$and $\mathrm{K}^{+}+\mathrm{Ca}^{2+} / \mathrm{Na}^{+}$were significantly increased by the two levels (i.e., 10 and $20 \mathrm{mM}$ ) of MAP compared to the controls (without MAP). The two MAP levels conferred the same results for most of the all tested parameters; particularly growth and yields characteristics, with some exceptions. Therefore, results of this study recommend using $10 \mathrm{mM}$ MAP as foliar application to optimize the common bean performances in saline soils.
\end{abstract}

\section{Introduction}

Worldwide, sustainable agriculture and human nutrition face many problems due to increasing the environmental stresses and climate change. Legumes may be considered as one of the solutions that need to be taken into account. As a human dietary nutrition, they are a healthpromoting source of protein, especially the common bean (Phaseolus vulgaris L.) that constitutes $50 \%$ of the total grain legumes consumed globally [1]. For sustainable agriculture, their cultivation is beneficial to non-legume crops through multiple agro-ecological services such as biological nitrogen fixation, improvement of soil fertility and N-rich green manure $[2,3]$. However, the economical, nutritional and ecological services provided by legumes are often compromised by sensitivity to environmental stresses whose increased frequency can reduce major crop production by more than half [4].

Among the most important vegetable legumes crops, Phaseolus vulgaris (L.) is produced for human nutrition, particularly in the Middle Eastern, including Egypt. It is classified as a saltsensitive plant [5].

Soil salinity is one of the major problems of agriculture, particularly in arid and semiarid regions, limiting plant growth and productivity [6-9]. Salt stress adversely affects plant morphology and physiology through osmotic and ionic stresses, and changes biochemical responses in plants [10]. It causes an overproduction of reactive oxygen species (ROS) such as superoxide $\left(\mathrm{O}_{2}{ }^{-}\right)$, hydrogen peroxide $\left(\mathrm{H}_{2} \mathrm{O}_{2}\right)$ and hydroxyl $\left(\mathrm{OH}^{--}\right)$radicals. Chloroplasts are the major organelles that produce the ROS during photosynthesis [11-13]. The ROS cause damages for lipids, proteins and DNA [14]. They also cause chlorophyll degradation and membrane lipid peroxidation [15]. Removal of the toxic ROS rapidly is important in any defense mechanism. This elimination occurs 
through antioxidant defense systems [16]. There are several reports underlining the intimate relationship between the activity of antioxidant systems and increased tolerance to environmental stresses $[6-9,17]$. Differences in the accumulation patterns of $\mathrm{Na}^{+}$and $\mathrm{K}^{+}$are found under salinity stress. Many salt tolerant species maintain a high $\mathrm{K}^{+}$content accompanied by a higher $\mathrm{K}^{+} / \mathrm{Na}^{+}$ratio $[6,8,18]$.

Application of phosphorus (P) can positively change the nutritional imbalance [19], optimizing the nutrient uptake capacity [6]. Nutrient uptake limitation under adverse conditions, particularly $\mathrm{P}$ assimilation, is one of the most limiting factors decreasing biomass and grain yield in $P$. vulgaris [2]. This nutrient deficiency is widespread with greater than $30 \%$ of the world's arable land affected by a $\mathrm{P}$ limitation [20]. The interaction between salinity and $\mathrm{P}$ positively affects plant growth and yield [6]. By increasing $\mathrm{P}$ application, there is an increased salt tolerance in plants [21]. Legumes are highly P-demanding crops; thus, $\mathrm{P}$ limitation negatively affects growth and symbiotic $\mathrm{N}_{2}$ fixation [22]. It has been hypothesized that legumes respond positively to increasing $\mathrm{P}$ supply under soil salinity and P-deficiency conditions. Increasing $\mathrm{P}$ supply can buffer legume performances against the soil salinity effects, particularly decreases in essential nutrients' absorptive capacity and subsequent yield instability. The magnitude of these growth limitations are reduced through a number of P-induced physiological changes such as stimulation of biosynthesis and accumulation of nitrogenous osmolytes, antioxidant reactions and affected photosynthetic activity and growth and yield of salt-stressed plants [6].

Accordingly, the present work was designed with the objective to assess the potential utilization effects of $\mathrm{P}$ (mono-ammonium phosphate; MAP, $\mathrm{NH}_{4} \mathrm{H}_{2} \mathrm{PO}_{4}$ ) as foliar application on the changes in the growth and green and dry yields characteristics, leaf photosynthetic pigments, chlorophyll fluorescence, and leaf contents of nutrients of Phaseolus vulgaris L. plants exposed to soil salinity stress $\left(E_{\mathrm{e}}=7.80-7.86 \mathrm{dS} \mathrm{m}^{-1}\right)$. The objective of the current study also aimed to establish a relationship between the changes in nutrient contents, especially $\mathrm{P}$ and the degree of plant tolerance, in terms of improvements in plant growth and yields.

\section{Materials and Methods}

\section{Experimental site, soil analyses, materials and treatments}

Two field experiments were conducted during the early (end of February) summer seasons of 2016 and 2017 at the Experimental Farm of the Faculty of Agriculture, Fayoum University, Southeast Fayoum $\left(29^{\circ} 17^{\prime} \mathrm{N} ; 30^{\circ} 53^{\prime} \mathrm{E}\right)$, Egypt. Assessments of the main soil chemical and physical characteristics (Table 1) were performed according to the procedures of Page et al. [23] and Klute [24]. Based on the determined $\mathrm{EC}_{\mathrm{e}}$ values in both seasons (7.86 and $7.80 \mathrm{dS} \mathrm{m}^{-1}$, respectively), the soil is classed as being saline according to Dahnke and Whitney [25].

The area of study is characterized by a dry climate [26]. Daily temperatures ranged from 14.1 to $26.9{ }^{\circ} \mathrm{C}$ with an average of $20.5-2.7^{\circ} \mathrm{C}$, and daily relative humidity averaged $54-4.6 \%$, in a range between 22 and $83 \%$ [6].

MAP used was purchased (Ujjain, Madhya Pradesh, India) and found to contain 48-61\% $\mathrm{P}_{2} \mathrm{O}_{5}$ and $10-12 \% \mathrm{~N}$. It was used at three levels (i.e., 0,10 or $20 \mathrm{mM}$ ). The selected levels of MAP for the two main field experiments were based on a pot preliminary study. We have used five levels; $0,5,10,20$, and $40 \mathrm{mM}$ of MAP. The two levels 10 and $20 \mathrm{mM}$ of MAP conferred the highest results (data not shown), therefore, we have used these two best levels in addition to the zero level as a control for the main field experiments. 
Table 1. Physical and chemical properties of the experimental soil during soil preparation for sowing in two seasons

\begin{tabular}{|c|c|c|}
\hline Parameter & 2016 season & 2017 season \\
\hline Clay & 41.0 & 40.5 \\
\hline Silt & 35.5 & 35.0 \\
\hline Sand & 23.5 & 24.5 \\
\hline Soil texture & \multicolumn{2}{|c|}{ Clay loam } \\
\hline $\mathrm{pH}$ & 7.79 & 7.76 \\
\hline $\mathrm{EC}_{\mathrm{e}}\left(\mathrm{dS} \mathrm{m}^{-1}\right)$ & 7.86 & 7.80 \\
\hline Organic matter $(\%)$ & 0.81 & 0.84 \\
\hline $\mathrm{CEC}^{*}\left(\mathrm{cmol}_{\mathrm{c}} \mathrm{kg}^{-1}\right)$ & 5.54 & 5.60 \\
\hline Field capacity $(\%)$ & 32.6 & 32.8 \\
\hline Available water $(\%)$ & 28.4 & 28.8 \\
\hline Available $\mathrm{N}$ ( $\mathrm{mg} \mathrm{kg}^{-1}$ soil) & 111.7 & 122.8 \\
\hline Available $\mathrm{P}\left(\mathrm{mg} \mathrm{kg}^{-1}\right.$ soil) & 16.4 & 18.9 \\
\hline Available $\mathrm{K}$ ( $\mathrm{mg} \mathrm{kg}^{-1}$ soil) & 142.8 & 151.3 \\
\hline Available Fe (mg kg${ }^{-1}$ soil $)$ & 45.1 & 46.3 \\
\hline Available Mn (mg kg${ }^{-1}$ soil) & 22.4 & 22.9 \\
\hline Available $\mathrm{Zn}$ ( $\mathrm{mg} \mathrm{kg}^{-1}$ soil) & 11.0 & 11.6 \\
\hline
\end{tabular}

"CEC; cation exchange capacity.

Healthy common bean (Phaseolus vulgaris L., cv. Bronco) seeds were obtained from The Horticulture Research Institute, Agricultural Research Centre, Giza, Egypt, and were sown on 27 February 2016, and on 26 February 2017. The common bean cultivar "Bronco" was used in this study because it is proved to be salt-sensitive [13]. Seeds were selected for uniformity by choosing those of equal size and same color. They were washed with distilled water, sterilized in $1 \%(\mathrm{v} / \mathrm{v})$ sodium hypochlorite for approximately $2 \mathrm{~min}$, and washed thoroughly again with distilled water. The sterilized seeds were left to dry at room temperature $\left(22 \pm 2{ }^{\circ} \mathrm{C}\right)$.

Commercial rhizobia inoculants were applied as peat slurry containing 107 Rhizobium $\mathrm{g}^{-1}$. Uniform, air-dried seeds were field sown on two different adjacent locations; one for 2016 season and the other for 2017 season, in the same Farm. Each location was divided into 9 experimental units allocated for 3 treatments ( 3 replicates per each) including the control. The recommended seed rate of 35-40 kg per feddan for common beans was used. Each experimental unit was consisted of five rows, $3 \mathrm{~m}$ long and $0.7 \mathrm{~m}$ wide (each unit $=10.5 \mathrm{~m}^{2}$ ), within row spacing was approximately $7.5 \mathrm{~cm}$. Thinning of plants (two per hill) was performed prior to the first irrigation. During preparation and plant growth, granular ammonium sulphate $[20.5 \%(\mathrm{w} / \mathrm{w}) \mathrm{N}]$ was applied at a rate equivalent to $30 \mathrm{~kg} \mathrm{~N} \mathrm{ha}^{-1}$, potassium sulphate $\left[48 \%(\mathrm{w} / \mathrm{w}) \mathrm{K}_{2} \mathrm{O}\right]$ was used at a rate equivalent to $30 \mathrm{~kg} \mathrm{~K} \mathrm{~K}_{2} \mathrm{O} \mathrm{ha}^{-1}$, calcium superphosphate $\left[15.5 \%(\mathrm{w} / \mathrm{w}) \mathrm{P}_{2} \mathrm{O}_{5}\right)$ was added at a rate equivalent to $60 \mathrm{~kg} \mathrm{P}_{2} \mathrm{O}_{5} \mathrm{ha}^{-1}$ as recommended for reclaimed saline soils [13].

The experimental design was complete randomized blocks with 3 levels of MAP, with three replicates per treatment. The experimental units were irrigated to that of reference crop evapotranspiration $\left(\mathrm{ET}_{0}\right)$ values according to Allen et al. [27]. The all other recommended agricultural practices for common beans were carried out as recommended by Abdelhamid et al. [28].

Foliar treatments of MAP were conducted for plant leaves to run off two times; at 25 (at approx. 4 true leaves) and 40 days (at approx. 6 true leaves) after sowing (DAS). Plants (approx. 200) of each experimental plot $\left(10.5 \mathrm{~m}^{2}\right)$ were sprayed with $2 \mathrm{~L}$ of P solution. Tween-20 was added at $0.1 \%(\mathrm{v} / \mathrm{v})$ to sprays as a surfactant to ensure optimal penetration into leaf tissues. The sprays were conducted at early morning before sunrise.

\section{Measurements of vegetative growth traits}

Fifty-day-old bean plants $(n=9)$ were removed and shoots were separated from plants, and the following vegetative growth attributes were recorded: Lengths of plants shoots were measured 
and number of leaves plant ${ }^{-1}$ was counted. Leaves area was measured using a leaf area meter (LICOR 3100C, LI-COR, Inc., Lincoln, NE, USA). Fresh weights of shoots were assessed, and dry weights of shoots were recorded after placing them in an oven at $70{ }^{\circ} \mathrm{C}$ until a constant weight.

\section{Yield characteristics assessments (green pods and dry seeds)}

At the marketable green pod stage of both experiments, green pods from randomly 5 rows (approximately 200 plants) from each treatment were collected, counted and weighed individually and per experimental plot $\left(10.5 \mathrm{~m}^{2}\right)$. At the end of both experiments, dry pods from the other 10 rows (approximately 400 plants) from each treatment were collected, seeds were extracted from pods, air-dried and weighed.

\section{Determination of leaf photosynthetic pigments contents}

Total chlorophylls and total carotenoids were extracted by homogenization of leaf sample $(0.2 \mathrm{~g})$ in $80 \%$ acetone $(50 \mathrm{ml})$. After filtration, the absorbance of the clear extract was measured at 663,646 and $470 \mathrm{~nm}[29]$.

\section{Determination of chlorophyll fluorescence}

Chlorophyll fluorescence was measured on two different sunny days using a portable fluorometer (Handy PEA, Hansatech Instruments Ltd, Kings Lynn, UK). One leaf (the same age) was chosen per plant from three plants in each experimental plot of each treatment. Fluorescence measurements included: Maximum quantum yield of PS II Fv/Fm was calculated as; Fv/Fm $=(\mathrm{Fm}$ - Fo)/Fm [30]. Performance index of photosynthesis based on the equal absorption (PIABS) was calculated as reported by Clark et al. [31].

\section{Determinations of $\mathrm{N}, \mathrm{P}, \mathrm{K}^{+}, \mathrm{Ca}^{2+}$, and $\mathrm{Na}^{+}$contents}

Content of $\mathrm{N}(\%)$ was determined in powdery dried material of plants by Orange-G dye colorimetric method according to Hafez and Mikkelsen [32].

The wet digestion of $0.1 \mathrm{~g}$ of fine dried material of plants was conducted using a sulphuric and perchloric acid mixture as mentioned by Piper [33]. The content of P (\%) was colorimetrically determined using chlorostannusmolybdo-phosphoric blue color method in sulphuric acid system as described by Jackson [34]. The content of $\mathrm{Ca}^{2+}(\%)$ was determined using a Perkin-Elmer Model 3300 Atomic Absorption Spectrophotometer [35]. The contents of $\mathrm{K}^{+}(\%)$ and $\mathrm{Na}^{+}(\%)$ were determined using a Perkin-Elmer Flame photometer [36].

\section{Calculations of $\mathrm{K}^{+} / \mathrm{Na}^{+}, \mathrm{Ca}^{2+} / \mathrm{Na}^{+}$and $\mathrm{K}^{+}+\mathrm{Ca}^{2+} / \mathrm{Na}^{+}$ratios}

The ratios of $\mathrm{K}^{+} / \mathrm{Na}^{+}, \mathrm{Ca}^{2+} / \mathrm{Na}^{+}$and $\mathrm{K}^{+}+\mathrm{Ca}^{2+} / \mathrm{Na}^{+}$were calculated from the determined contents of $\mathrm{K}, \mathrm{Ca}$ and $\mathrm{Na}$.

\section{Statistical analysis}

All values (in 9 samples per treatment; $n=9$ ) of the measured parameters for the common bean plants were subjected to statistical analysis following the standard procedures described by Gomez and Gomez [37]. Duncan's multiple range test was applied to assess the least significant difference (LSD) of each treatment at a probability level of $95 \%(P \leq 0.05)$.

\section{Results}

\section{Effect of foliar application with mono-ammonium phosphate (MAP) on growth traits of salt- stressed-common bean plants}

Foliar application with MAP at the two levels (10 and $20 \mathrm{mM})$ significantly increased the all tested growth characteristics (i.e., shoot length, number of leaves per plant, area of leaves per plant, and shoot fresh and dry weights) of salt-stressed common bean plants compared to the controls (without MAP) (Table 2). With some exceptions (i.e., leaves area per plant and shoot fresh weight) in which the level of $20 \mathrm{mM}$ MAP was significantly exceeded the level of $10 \mathrm{mM}$ MAP, the two 
levels showed no significant differences. Results of the two seasons showed the same trend. Foliar application of MAP at $10 \mathrm{mM}$ is found to be preferred treatment.

Table 2. Effect of foliar application with mono-ammonium phosphate (MAP) on growth traits of common bean (Phaseolus vulgaris L., cv. "Bronco") plants grown under soil salinity stress

\begin{tabular}{|c|c|c|c|c|c|c|c|c|c|c|}
\hline \multirow[b]{2}{*}{ Treatments } & \multicolumn{10}{|c|}{ Parameters } \\
\hline & $\begin{array}{l}\text { Shoot } \\
\text { length } \\
(\mathrm{cm})\end{array}$ & $\begin{array}{c}\% \text { of } \\
\text { control }\end{array}$ & $\begin{array}{l}\text { No. of } \\
\text { leaves } \\
\text { plant }^{-1}\end{array}$ & $\begin{array}{c}\% \text { of } \\
\text { control }\end{array}$ & $\begin{array}{l}\text { Leaf } \\
\text { area } \\
\text { plant }^{-1} \\
\left(\mathrm{dm}^{2}\right) \\
\end{array}$ & $\begin{array}{c}\% \text { of } \\
\text { control }\end{array}$ & $\begin{array}{l}\text { Shoot } \\
\text { fresh } \\
\text { weight } \\
(\mathrm{g})\end{array}$ & $\begin{array}{c}\% \text { of } \\
\text { control }\end{array}$ & $\begin{array}{l}\text { Shoot } \\
\text { dry } \\
\text { weight } \\
(\mathrm{g})\end{array}$ & $\begin{array}{c}\% \text { of } \\
\text { control }\end{array}$ \\
\hline \multicolumn{11}{|l|}{2016 season } \\
\hline Control & $25.4 \mathrm{~b}$ & - & $7.31 \mathrm{~b}$ & - & $9.51 \mathrm{c}$ & - & $25.0 \mathrm{c}$ & - & $5.74 b$ & - \\
\hline MAP1 & $27.1 \mathrm{a}$ & +6.7 & $7.63 \mathrm{a}$ & +4.4 & $10.31 b$ & +8.4 & $29.2 b$ & +16.8 & $6.91 \mathrm{a}$ & +20.4 \\
\hline MAP2 & $28.2 \mathrm{a}$ & +11.0 & $7.81 \mathrm{a}$ & +6.8 & $11.18 \mathrm{a}$ & +17.6 & $31.6 \mathrm{a}$ & +26.4 & $7.49 a$ & +30.5 \\
\hline \multicolumn{11}{|l|}{2017 season } \\
\hline Control & $26.1 \mathrm{~b}$ & - & $7.28 \mathrm{~b}$ & - & $9.58 \mathrm{c}$ & - & $25.8 \mathrm{c}$ & - & $5.87 \mathrm{~b}$ & - \\
\hline MAP1 & $27.8 \mathrm{a}$ & +6.5 & $7.66 a$ & +5.2 & $10.49 b$ & +9.5 & $30.0 \mathrm{~b}$ & +16.3 & $6.93 a$ & +18.1 \\
\hline MAP2 & $28.2 \mathrm{a}$ & +8.0 & $7.78 \mathrm{a}$ & +6.9 & $11.55 \mathrm{a}$ & +20.6 & $32.1 \mathrm{a}$ & +24.4 & $7.45 \mathrm{a}$ & +26.9 \\
\hline
\end{tabular}

Mean values $(\mathrm{n}=9)$ in each column for each year followed by a different lower-case letter are significantly different at $p \leq 0.05$ by Duncan's multiple range test. Control means plots without foliar application (MAP0), MAP1 means $10 \mathrm{mM}$ of mono-ammonium phosphate, and MAP2 means $20 \mathrm{mM}$ of mono-ammonium phosphate.

Effect of foliar application with mono-ammonium phosphate (MAP) on green pod and dry seed yields of salt-stressed-common bean plants

Foliar application with MAP at the two levels $(10$ and $20 \mathrm{mM})$ significantly increased the all tested green pods and dry seed yields characteristics [i.e., average pod weight, number of pods per plant, pods weight per plot $\left(10.5 \mathrm{~m}^{2}\right)$, dry seed weight per plot $\left(10.5 \mathrm{~m}^{2}\right)$ and 100 -seed weight] of salt-stressed common bean plants compared to the controls (without MAP) (Table 3). With an exception (i.e., pods weight per plant) in which the level of $20 \mathrm{mM}$ MAP was significantly exceeded the level of $10 \mathrm{mM}$ MAP, the two levels showed no significant differences. Results of the two seasons showed the same trend. Foliar application of MAP at $10 \mathrm{mM}$ is found to be preferred treatment.

\section{Effect of foliar application with mono-ammonium phosphate (MAP) on the contents of leaf photosynthetic pigments and chlorophyll fluorescence of salt-stressed-common bean plants}

Foliar application with MAP at the two levels (10 and $20 \mathrm{mM})$ significantly increased leaf photosynthetic pigments contents and chlorophyll flourescence (i.e., total chlorophylls, total carotenoids, Fv/Fm and PI) of salt-stressed common bean plants compared to the controls (without MAP) (Table 4). The two levels showed no significant differences. Results of the two seasons showed the same trend. Foliar application of MAP at $10 \mathrm{mM}$ is found to be preferred treatment. 
Table 3. Effect of foliar application with mono-ammonium phosphate (MAP) on green pod and dry seed yields of common bean (Phaseolus vulgaris L., cv. "Bronco") plants grown under soil salinity stress

\begin{tabular}{|c|c|c|c|c|c|c|c|c|c|c|}
\hline \multirow[b]{2}{*}{ Treatment } & \multicolumn{10}{|c|}{ Parameters } \\
\hline & $\begin{array}{c}\text { Pod } \\
\text { weight } \\
\text { (g) }\end{array}$ & $\begin{array}{c}\% \text { of } \\
\text { control }\end{array}$ & $\begin{array}{l}\text { Pods } \\
\text { No. } \\
\text { plant }^{-1}\end{array}$ & $\begin{array}{c}\% \text { of } \\
\text { control }\end{array}$ & $\begin{array}{l}\text { Pods } \\
\text { weight } \\
\text { plant }^{-1} \\
(\mathrm{~g})\end{array}$ & $\begin{array}{c}\% \text { of } \\
\text { control }\end{array}$ & $\begin{array}{l}\text { Dry seed } \\
\text { weight } \\
\text { plant }^{-1} \\
(\mathrm{~g})\end{array}$ & $\begin{array}{c}\% \text { of } \\
\text { control }\end{array}$ & $\begin{array}{c}100- \\
\text { seed } \\
\text { weight } \\
(\mathrm{g})\end{array}$ & $\begin{array}{c}\% \text { of } \\
\text { control }\end{array}$ \\
\hline \multicolumn{11}{|l|}{2016 season } \\
\hline Control & $2.20 \mathrm{~b}$ & - & $15.2 b$ & - & $31.5 \mathrm{c}$ & - & $10.6 b$ & - & $16.6 \mathrm{~b}$ & - \\
\hline MAP1 & $2.44 \mathrm{a}$ & +10.9 & $19.0 \mathrm{a}$ & +25.0 & $43.7 b$ & +38.7 & $11.9 \mathrm{a}$ & +12.3 & $18.4 \mathrm{a}$ & +10.8 \\
\hline MAP2 & $2.54 \mathrm{a}$ & +15.5 & $20.6 \mathrm{a}$ & +35.5 & $49.4 \mathrm{a}$ & +56.8 & $12.4 \mathrm{a}$ & +17.0 & $19.4 \mathrm{a}$ & +16.9 \\
\hline \multicolumn{11}{|l|}{2017 season } \\
\hline Control & $2.24 b$ & - & $15.5 b$ & - & $32.6 \mathrm{c}$ & - & $10.8 b$ & - & $17.2 \mathrm{~b}$ & - \\
\hline MAP1 & $2.49 \mathrm{a}$ & +11.2 & $19.3 \mathrm{a}$ & +24.5 & $45.4 \mathrm{~b}$ & +39.3 & $12.0 \mathrm{a}$ & +11.1 & $18.9 \mathrm{a}$ & +9.9 \\
\hline MAP2 & $2.60 \mathrm{a}$ & +16.1 & $21.0 \mathrm{a}$ & +35.5 & $51.4 \mathrm{a}$ & +57.7 & $12.8 \mathrm{a}$ & +18.5 & $19.9 \mathrm{a}$ & +15.7 \\
\hline
\end{tabular}

Mean values in each column for each year followed by a different lower-case letter are significantly different at $p \leq 0.05$ by Duncan's multiple range test. Control means plots without foliar application (MAP0), MAP1 means $10 \mathrm{mM}$ of mono-ammonium phosphate, and MAP2 means $20 \mathrm{mM}$ of mono-ammonium phosphate.

Table 4. Effect of foliar application with mono-ammonium phosphate (MAP) on leaf photosynthetic pigments contents ( $\mathrm{mg} \mathrm{g}^{-1}$ fresh weight) and chlorophyll fluorescence of common bean (Phaseolus vulgaris L., cv. "Bronco") plants grown under soil salinity stress

\begin{tabular}{|c|c|c|c|c|c|c|c|c|}
\hline \multirow[b]{2}{*}{ Treatments } & \multicolumn{8}{|c|}{ Parameters } \\
\hline & $\begin{array}{c}\text { Total } \\
\text { chlorophylls }\end{array}$ & $\begin{array}{c}\% \text { of } \\
\text { control }\end{array}$ & $\begin{array}{c}\text { Total } \\
\text { carotenoids }\end{array}$ & $\begin{array}{c}\% \text { of } \\
\text { control }\end{array}$ & $\mathrm{Fv} / \mathrm{Fm}$ & $\begin{array}{c}\% \text { of } \\
\text { control }\end{array}$ & PI & $\begin{array}{c}\% \text { of } \\
\text { control }\end{array}$ \\
\hline \multicolumn{9}{|l|}{2016 season } \\
\hline Control & $0.96 b$ & - & $0.32 b$ & - & $67.5 b$ & - & $60.6 \mathrm{~b}$ & - \\
\hline MAP1 & $1.64 \mathrm{a}$ & +70.8 & $0.38 \mathrm{a}$ & +18.8 & $79.4 \mathrm{a}$ & +17.6 & $71.7 \mathrm{a}$ & +18.3 \\
\hline MAP2 & $1.67 \mathrm{a}$ & +74.0 & $0.41 \mathrm{a}$ & +28.1 & $82.3 \mathrm{a}$ & +21.9 & $74.2 \mathrm{a}$ & +22.4 \\
\hline \multicolumn{9}{|l|}{2017 season } \\
\hline Control & $0.99 b$ & - & $0.34 b$ & - & $68.2 \mathrm{~b}$ & - & $61.0 \mathrm{~b}$ & - \\
\hline MAP1 & $1.62 \mathrm{a}$ & +63.6 & $0.43 \mathrm{a}$ & +26.5 & $81.2 \mathrm{a}$ & +19.1 & $72.4 \mathrm{a}$ & +18.7 \\
\hline MAP2 & $1.70 \mathrm{a}$ & +71.7 & $0.45 \mathrm{a}$ & +32.4 & $83.5 \mathrm{a}$ & +22.4 & $74.4 \mathrm{a}$ & +22.0 \\
\hline
\end{tabular}

Mean values $(\mathrm{n}=9)$ in each column for each year followed by a different lower-case letter are significantly different at $p \leq 0.05$ by Duncan's multiple range test. Control means plots without foliar application (MAP0), MAP1 means $10 \mathrm{mM}$ of mono-ammonium phosphate, and MAP2 means $20 \mathrm{mM}$ of mono-ammonium phosphate.

\section{Effect of foliar application with mono-ammonium phosphate (MAP) on leaf contents of nutrients and sodium of salt-stressed-common bean plants}

Foliar application with MAP at the two levels $(10$ and $20 \mathrm{mM})$ significantly increased leaf contents of nitrogen $(\mathrm{N})$, phosphorus $(\mathrm{P})$, potassium $\left(\mathrm{K}^{+}\right)$, and calcium $\left(\mathrm{Ca}^{2+}\right)$, while significantly reduced leaf sodium $\left(\mathrm{Na}^{+}\right)$of salt-stressed common bean plants compared to the controls (without MAP) (Table 5). With some exceptions (i.e., $\mathrm{K}^{+}$and $\mathrm{Na}^{+}$) in which the level of $20 \mathrm{mM}$ MAP was significantly exceeded (the increase for $\mathrm{K}^{+}$and the decrease for $\mathrm{Na}^{+}$) the level of $10 \mathrm{mM}$ MAP, the two levels showed no significant differences. Results of the two seasons showed the same trend. Foliar application of MAP at $10 \mathrm{mM}$ is found to be preferred treatment. 
Table 5. Effect of foliar application with mono-ammonium phosphate (MAP) on the contents of macro-nutrients $\left(\mathrm{N}, \mathrm{P}, \mathrm{K}^{+}\right.$and $\mathrm{Ca}^{2+}$ ) and sodium $\left(\mathrm{Na}^{+}\right)$of common bean (Phaseolus vulgaris L., cv. "Bronco") plants grown under soil salinity stress

\begin{tabular}{|c|c|c|c|c|c|c|c|c|c|c|}
\hline \multirow[b]{2}{*}{ Treatments } & \multicolumn{10}{|c|}{ Parameters } \\
\hline & $\mathrm{N}(\%)$ & $\begin{array}{c}\% \text { of } \\
\text { control }\end{array}$ & $\mathrm{P}(\%)$ & $\begin{array}{c}\% \text { of } \\
\text { control }\end{array}$ & $\mathrm{K}^{+}(\%)$ & $\begin{array}{c}\% \text { of } \\
\text { control }\end{array}$ & $\mathrm{Ca}^{2+}(\%)$ & $\begin{array}{c}\% \text { of } \\
\text { control }\end{array}$ & $\mathrm{Na}^{+}(\%)$ & $\begin{array}{c}\% \text { of } \\
\text { control }\end{array}$ \\
\hline \multicolumn{11}{|l|}{2016 season } \\
\hline Control & $2.64 b$ & - & $0.28 b$ & - & $2.55 \mathrm{c}$ & - & $1.09 \mathrm{~b}$ & - & $0.64 a$ & - \\
\hline MAP1 & $3.06 \mathrm{a}$ & +15.9 & $0.49 \mathrm{a}$ & +75.0 & $2.91 \mathrm{~b}$ & +14.1 & $1.20 \mathrm{a}$ & +10.1 & $0.44 b$ & -31.3 \\
\hline MAP2 & $3.19 \mathrm{a}$ & +20.8 & $0.52 \mathrm{a}$ & +85.7 & $3.11 \mathrm{a}$ & +22.0 & $1.28 \mathrm{a}$ & +17.4 & $0.39 \mathrm{c}$ & -39.1 \\
\hline \multicolumn{11}{|l|}{2017 season } \\
\hline Control & $2.71 \mathrm{~b}$ & - & $0.27 \mathrm{~b}$ & - & $2.59 \mathrm{c}$ & - & $1.03 \mathrm{~b}$ & - & $0.62 \mathrm{a}$ & - \\
\hline MAP1 & $3.08 \mathrm{a}$ & +13.7 & $0.50 \mathrm{a}$ & +85.2 & $3.04 \mathrm{~b}$ & +17.4 & $1.21 \mathrm{a}$ & +17.5 & $0.42 b$ & -32.3 \\
\hline MAP2 & $3.24 \mathrm{a}$ & +19.6 & $0.52 \mathrm{a}$ & +92.6 & $3.26 \mathrm{a}$ & +25.9 & $1.29 \mathrm{a}$ & +25.2 & $0.37 \mathrm{c}$ & -40.3 \\
\hline
\end{tabular}

Mean values $(n=9)$ in each column for each year followed by a different lower-case letter are significantly different at $p \leq 0.05$ by Duncan's multiple range test. Control means plots without foliar application (MAP0), MAP1 means $10 \mathrm{mM}$ of mono-ammonium phosphate, and MAP2 means $20 \mathrm{mM}$ of mono-ammonium phosphate.

\section{Effect of foliar application with mono-ammonium phosphate (MAP) on antagonistic relations of} $\mathrm{K}^{+}$and $\mathrm{Ca}^{2+}$ with $\mathrm{Na}^{+}$of salt-stressed-common bean plants

Foliar application with MAP at the two levels $(10$ and $20 \mathrm{mM})$ significantly increased the ratios of $\mathrm{K}^{+} / \mathrm{Na}^{+}, \mathrm{Ca}^{2+} / \mathrm{Na}^{+}$, and $\mathrm{K}^{+}+\mathrm{Ca}^{2+} / \mathrm{Na}^{+}$in salt-stressed common bean plants compared to the controls (without MAP) (Table 6). In addition, the level of 20 mM MAP was significantly exceeded the level of $10 \mathrm{mM}$ MAP for the all ratios. Results of the two seasons showed the same trend.

Table 6. Effect of foliar application with mono-ammonium phosphate (MAP) on nutrient relations with sodium $(\mathrm{Na})$ ions in common bean (Phaseolus vulgaris L., cv. "Bronco") plants grown under soil salinity stress

\begin{tabular}{|c|c|c|c|c|c|c|}
\hline \multirow[b]{2}{*}{ Treatments } & \multicolumn{6}{|c|}{ Parameters } \\
\hline & $\mathrm{K}^{+} / \mathrm{Na}^{+}$ratio & $\%$ of control & $\begin{array}{l}\mathrm{Ca}^{2+} / \mathrm{Na}^{+} \\
\text {ratio }\end{array}$ & $\begin{array}{l}\% \text { of } \\
\text { control }\end{array}$ & $\begin{array}{c}\mathrm{K}^{+}+\mathrm{Ca}^{2+} / \mathrm{Na}^{+} \\
\text {ratio }\end{array}$ & $\%$ of control \\
\hline \multicolumn{7}{|l|}{2016 season } \\
\hline Control & $3.75 \mathrm{c}$ & - & $1.61 \mathrm{c}$ & - & $5.37 \mathrm{c}$ & - \\
\hline MAP1 & $6.20 \mathrm{~b}$ & +65.3 & $2.56 \mathrm{~b}$ & +59.0 & $8.75 b$ & +62.9 \\
\hline MAP2 & $7.47 \mathrm{a}$ & +99.2 & $3.05 \mathrm{a}$ & +89.4 & $10.54 \mathrm{a}$ & +96.3 \\
\hline \multicolumn{7}{|l|}{2017 season } \\
\hline Control & $3.93 \mathrm{c}$ & - & $1.57 \mathrm{c}$ & - & $5.52 \mathrm{c}$ & - \\
\hline MAP1 & $6.75 b$ & +71.8 & $2.70 \mathrm{~b}$ & +72.0 & $9.47 \mathrm{~b}$ & +71.6 \\
\hline MAP2 & $8.37 \mathrm{a}$ & +113.0 & $3.30 \mathrm{a}$ & +110.2 & $11.69 \mathrm{a}$ & +111.8 \\
\hline
\end{tabular}

Mean values $(n=9)$ in each column for each year followed by a different lower-case letter are significantly different at $p \leq 0.05$ by Duncan's multiple range test. Control means plots without foliar application (MAP0), MAP1 means $10 \mathrm{mM}$ of mono-ammonium phosphate, and MAP2 means $20 \mathrm{mM}$ of mono-ammonium phosphate.

\section{Discussion}

In dry environments including Egypt, agricultural sector faces a massive problem due to salinity. Salinity occurred in growing media in such regions could be caused by one or more of the following reasons: (1) poor irrigation water which contains considerable amounts of salts, (2) accumulation of salts in the top layer of the soil due to over-irrigation, (3) proximity to the sea, (4) capillarity rise of salts from underground water into the root zone due to excessive evaporation, (5) low rainfall, (6) high evaporation rate, and (6) poor water management [38, 39]. These soil salinization causes expose plants to osmotic stress. Salt stress adversely affects plant performance due to stimulating the overproduction of reactive oxygen species (ROS) through various organelles 
and enzymes [40]. To avoid these effects, plants adopt several strategies such as ion homeostasis, osmotic adjustment and enhancing the antioxidative defense system [41].

In the current study, soil salinity caused a significant reduction in common bean growth characteristics (Table 2), and a considerable loss in green pod and dry seed yields was also noted (Table 3). These results are in agreement with those obtained by some researchers [13, 42, 43] with most plant species. Plant productivity negatively affected by the toxic effects of soil salinity stress as a result in the increased accumulation of $\mathrm{Na}^{+}$(Table 8) and $\mathrm{Cl}^{-}$ions in bean leaves [13]. Therefore, biomass production inserted to be one of the most agricultural indices is used to define salt-stress tolerance [44]. The increased accumulation of $\mathrm{Na}^{+}$and $\mathrm{Cl}^{-}$ions can disturb or upset the ionic balance, inducing a nutritional imbalance due to the blockage of other cations such as $\mathrm{K}^{+}$, $\mathrm{Ca}^{2+}, \mathrm{Mg}^{2+}$ or anions such as $\mathrm{NO}_{3}^{-}$and thereby the induction of nutritional deficiency symptoms [45], which were appeared and noted as yellowing on leaves of common bean plants in the current study (data not shown). This symptom was reflected in the significant reduction of leaf chlorophylls (Table 4). The maintenance of the ionic balance during salinity stress is prerequisite to protect the plant against the build-up of toxic ions, with $\mathrm{K}^{+}$accumulating and $\mathrm{Na}^{+}$reaching the minimum content in common bean leaves (Table 8). Thus, the control of $\mathrm{Na}^{+}$accumulation and therefore higher $\mathrm{K}^{+} / \mathrm{Na}^{+}[46]$ and $\mathrm{Ca}^{2+} / \mathrm{Na}^{+}$ratios (Table 9) may strengthen salinity tolerance in common bean plants.

Several studies have shown to use phosphorus (P), as exogenous supports, to alleviate the plant cytotoxicity induced by salt stress $[6,47,48]$. These applications have proved to enhance the natural antioxidative defense systems of plants, offering the opportunity for in-field protection against the dangerous salt stress.

Exploring suitable stress alleviant applied for soil is one of the plant biologist tasks. In recent decades, fertilizers applied for growing media (i.e., N, K, S and P, ... etc.) have been found to be effective in mitigating the salt induced damages in plants [6, 47-49]. These amendments donated the capacity, in different degrees, to improve the plant's growth and productivity, as well as stress tolerance under salinity.

Application of P (i.e., MAP as foliar spray) significantly improved growth characteristics and yields of bean plants grown under saline soil (7.80-7.86 $\mathrm{dS} \mathrm{m}^{-1}$ ) conditions (Tables 2 and 3). MAP foliar application alleviated the harmful effects of salt stress on growth and yields of some crops $[47,48,50]$. Growth parameters of common bean plants grown under soil salinity stress responded positively to $P$ in our study. The loss of growth and consequently in yield components under salt stress may be attributed to the decreases in photosynthetic pigments (Table 4) and disturbance in the nutrients' balance (Tables 5 and 6). However, MAP caused significant increases in growth and yields of salt-stressed common bean plants compared with the controls (Tables 2 and 3 ). Application of $\mathrm{P}$ fertilizer is necessary to ensure optimum plant production and quality [51], as well as for the acquisition, storage, and use of energy [52]. The present study demonstrated the positive relationship between $\mathrm{P}$ application and plant growth, which is supported by previous findings that $\mathrm{P}$ application increases plant height and root collar diameter [53], as well as basal stem diameter [47], and that $\mathrm{P}$ application has a positive effect on the growth of some plant species $[48,50,54]$. It is known that leaf development depends on a high degree of $\mathrm{P}$ concentration in the tissue because $\mathrm{P}$ plays an important role in the synthesis of sucrose and starch in photosynthesis, which increases plant dry weight [55]. Sufficient P makes efforts to increase dry matter accumulation by increasing the photosynthesis product of root and shoot, and consequently the increase in yields components.

Salt stress partially inhibited photosynthesis by a reduction in leaf photosynthetic pigments and chlorophyll fluorescence (Fv/Fm and PI); Table 4. However, foliar MAP application increased these attributes, protecting photosynthetic machinery from salt-induced ROS by acting as a free radical scavenger. Leaf chlorophyll, as a biochemical attribute, is among the most important physiological indicators reflecting the stress of the plant in part due to its reliance on water and nutritional availability $[56,57]$. In this study, salinity stress caused a decrease in total chlorophylls and total carotenoids in common bean leaves. It has been reported that strong evidence that total chlorophyll in the leaves of common bean and plant dry weight, and total chlorophyll and seed yield 
per hectare at harvest are highly associated with one another in a linear way under saline conditions [6]. In addition, total carotenoids in the leaves of common bean and seed yield per hectare are highly associated with one another in a linear way under salt stress. The reduction in chlorophyll in the stressed plants might be due to the disorganization of thylakoid membranes, more degradation than synthesis of chlorophyll via the formation of proteolytic enzymes such as chlorophyllase, which is responsible for the chlorophyll degradation and damaging to the photosynthetic apparatus [58], and this should result in reducing plant net assimilation rate and relative growth rate [57], in addition to the inhibitory effect of the accumulated ions [59,60].

Chlorophyll and carotenoid synthesis are dependent upon mineral nutrition [61]. Leaf green pigments depend on $\mathrm{P}$ content, since it facilitates the plant for stability in unfavorable conditions [62]. However, the facilitation of biochemical characteristics and biosynthesis of pigment molecules depends on the uptake of optimal P levels $[48,63]$. Optimal P conditions, in apricot seedlings, have been shown to increase total chlorophyll content and plant growth [64]. Previous studies have also reported that $\mathrm{P}$ application increases the biomass and carotenoid production of a blue-green alga Spirulina platensis [65], whereas $\mathrm{P}$ deficiency decreases protein and chlorophyll contents [66]. The $\mathrm{Fv} / \mathrm{Fm}$ and PI are used as a noninvasive method to determine the functional state of photosynthetic machinery. These physiological attributes were reduced significantly by salt stress, while foliar MAP application significantly improved these attributes in leaves of salt-stressed plants (Table 4).

Foliar MAP application mitigates the adverse effects of salt stress, leading to an increase in the contents of nutrients (Table 5) and their relations with $\mathrm{Na}^{+}$(i.e., $\mathrm{K}^{+} / \mathrm{Na}^{+}, \mathrm{Ca}^{2+} / \mathrm{Na}^{+}$and $\mathrm{K}^{+}+\mathrm{Ca}^{2+} / \mathrm{Na}^{+}$; Table 6). In this connection, it has been suggested that increased accumulation of $\mathrm{Na}^{+}$ and $\mathrm{Cl}^{-}$ions in the tissues under salt stress inhibits biochemical processes related to photosynthesis through direct toxicity, leading to low water potential [67]. The promotion of $\mathrm{Na}^{+}$ion uptake under salt stress was accompanied by a corresponding decline in $\mathrm{K}^{+}$content, showing an antagonism between $\mathrm{K}^{+}$and $\mathrm{Na}^{+}$[18]. The selectivity of high $\mathrm{K}^{+} / \mathrm{Na}^{+}$ratio in plants is considered an important mechanism and criterion selection for salt tolerance [68]. It has been reported that better plant tolerance to salt stress is primarily due to better $\mathrm{K}^{+}$assimilation, resulting in higher $\mathrm{K}^{+} / \mathrm{Na}^{+}$ratio. In addition, maintenance of $\mathrm{Ca}^{2+}$ acquisition and transport under salt stress is an important determinant of salt tolerance [69]. The $\mathrm{Ca}^{2+}$ is known to play an important role in maintaining the structural and functional integrity of cell membranes, stabilizing the cell walls and regulating the ion transport, as well as the selectivity and activation of cell wall enzymes [70].

Differences in nutrient concentrations have revealed clear biochemical differences in plants in their response to salinity and MAP treatment. Previous researches have shown that varying levels of salinity significantly increased $\mathrm{Na}^{+}$contents in different plant cultivars $[71,72]$. The increase in leaf $\mathrm{Na}^{+}$content may be due to increased concentrations of $\mathrm{Na}^{+}$in the growing medium ultimately resulting in the increased uptake of $\mathrm{Na}^{+}$by plant [59]. Our findings here portray through a decrease in $\mathrm{Na}^{+}$content by the increase in $\mathrm{P}$ supply. Moreover, it has been reported that $\mathrm{Na}^{+}$in the leaves of common bean and seed yield per hectare are highly associated with one another in a linear way under salt stress [6]. This may be attributed to the positive role of $\mathrm{P}$ in improved plant growth (Table 2), increased contents of photosynthetic pigments (Table 4), and increased nutrient contents, especially $\mathrm{P}$ (Table 5), consequently increasing the plant adaptive capacity to salinity by exclusion of $\mathrm{Na}^{+}$[73]. Soil salinity significantly reduced $\mathrm{K}^{+}$content in common bean leaves due to that salinity could be related to a gradient competition and resulting in selective uptake between $\mathrm{K}^{+}$and $\mathrm{Na}^{+}$, which causes an increase in uptake of $\mathrm{Na}^{+}$at the cost of $\mathrm{K}^{+}$[74] or decline in $\mathrm{K}^{+}$content occurs due to a decrease in sink size under salinity conditions.

Malik et al. [75] have reported that synergistic relationship between $\mathrm{P}$ and other beneficial elements like $\mathrm{K}^{+}$and $\mathrm{Ca}^{2+}$ might have initiated an osmotic effect and thus can be held responsible for salt tolerance to some degree. Our results confirmed these results where $\mathrm{P}$ application increased $\mathrm{N}, \mathrm{P}, \mathrm{K}^{+}$, and $\mathrm{Ca}^{2+}$ contents, while reduced $\mathrm{Na}^{+}$content. Foliar MAP application increased the all tested nutrients contents and the $\mathrm{K}^{+} / \mathrm{Na}^{+}$and $\mathrm{Ca}^{2+} / \mathrm{Na}^{+}$ratios, and consequently $\mathrm{K}^{+}+\mathrm{Ca}^{2+} / \mathrm{Na}^{+}$ratio, indicating a salt tolerance of common bean is associated with an enhanced $\mathrm{K}^{+} / \mathrm{Na}^{+}$and $\mathrm{Ca}^{2+} / \mathrm{Na}^{+}$ ratios discrimination trait $[6,59]$. Precisely, the contents of $\mathrm{K}^{+}$and $\mathrm{Ca}^{2+}$ were significantly increased 
in common bean plants foliarly supplemented with MAP, which may underline a mechanism behind the sensitivity of common bean plant that is likely associated with low nutrient uptake capacity. The contents of $\mathrm{P}$ and $\mathrm{N}$ were increased significantly under salinity stress with foliar application of MAP. The application of $\mathrm{P}$ increased $\mathrm{P}$ content rather than $\mathrm{N}$. The nutrient $\mathrm{P}$ is stored in vacuoles, yet the mobility of $\mathrm{P}$ may be decreased by the presence of salinity, consequently an inhibition of export from this storage in particular to other parts of the plant. In addition, Grattan and Grieve [76] have attributed the reduction in $\mathrm{P}$ nutrient availability due to ionic strength effects which can reduce phosphate activity. In addition, Bargaz et al. [6] have found that $\mathrm{P}$ content and seed yield per hectare are highly associated with one another in a linear way under salt stress.

\section{Conclusions}

Foliar application of MAP to salt-stressed plants has been shown to enhance plant salt stressdefense responses, to act directly and/or indirectly at improving total plant performances (growth and yields) under salt stress via increasing the photosynthetic efficiency (i.e., Fv/Fm and PI). Thus, MAP may provide an effective strategy to alleviate the adverse effects of salt stress through increased N-utilization, resulting in less damage to photosynthesis and greater protection of dangerous effects of salt stress. Therefore, foliar application of MAP may act to alleviate the severity of the effects of salt stress on Phaseolus vulgaris plants grown on saline soils.

\section{Conflict of Interest}

The authors declare that there is no conflict of interest.

\section{References}

[1] W.J. Broughton, G. Hernander, B. Blair, S. Beebe, P. Gepts, J. Vanderleyden, Beans (Phaseolus spp.) - model food legumes, Plant and Soil. 252 (2003) 55-128.

[2] C.P. Vance, Symbiotic nitrogen fixation and phosphorus acquisition. Plant nutrition in a world of declining renewable resources, Plant Physiology. 127 (2001) 390-397.

[3] M.E. Isaac, J.M. Harmand, J.J. Drevon, Growth and nitrogen acquisition strategies of Acacia senegal seedlings under exponential phosphorus additions, Journal of Plant Physiology. 168 (2011) 776-781.

[4] X.W. Wang, B. Vinocur, A. Altman, Plant responses to drought, salinity and extreme temperatures: towards genetic engineering for stress tolerance, Planta. 218 (2003) 1-14.

[5] E.V. Maas, G.J. Hoffman, Crop salt tolerance-Current assessment, Journal of the Irrigation and Drainage Division - PUBDB. 103(2) (1977) 115-134.

[6] A. Bargaz, R.M.A. Nassar, M.M. Rady, M.S. Gaballah, S.M. Thompson, M. Brestic, U. Schmidhalter, M.T. Abdelhamid, Improved salinity tolerance by phosphorus fertilizer in two Phaseolus vulgaris recombinant inbred lines contrasting in their P-efficiency, Journal of Agronomy and Crop Science. 202 (2016) 497-507.

[7] M.M. Rady, T.A. Abd El-Mageed, H.A. Abdurrahman, A.H. Mahdi, Humic acid application improves field performance of cotton (gossypium barbadense L.) under saline conditions, Journal of Animal and Plant Science. 26(2) (2016) 487-493.

[8] M.M. Rady et al., Growth, heavy metal status and yield of salt-stressed wheat (Triticum aestivum L.) plants as affected by the integrated application of bio-, organic and inorganic nitrogen-fertilizers, Journal of Applied Botany and Food Quality. 89 (2016b) 21-28.

[9] M.M. Rady, R.S. Taha, A.H.A. Mahdi, Proline enhances growth, productivity and anatomy of two varieties of Lupinus termis L. grown under salt stress, South African Journal of Botany. 102 (2016) 221-227.

[10] M.I. Khan, A. Mughal, N. Iqbal, N.A. Khan, Potentiality of sulphur containing compounds in salt stress tolerance. In: Parvaiz, A., Azooz, M. M., Prasad, M. N. V. (Eds.). Ecophysiology and responses of plants under salt stress. Chapter 17 (2013) p: 443-472, Springer. 
[11] K. Asada, The water-water cycle in chloroplasts: Scavenging of active oxygens and dissipation of excess photons, Annual Review of Plant Physiology and Plant Molecular Biology. 50 (1999) 601-639.

[12] S.A. Orabi, M.T. Abdelhamid, Protective role of a-tocopherol on two Vicia faba cultivars against seawater-induced lipid peroxidation by enhancing capacity of anti-oxidative system, Journal of the Saudi Society of Agricultural Sciences. 15 (2016) 145-154.

[13] Kh.A. Hemida, A.Z.A. Eloufey, M.A. Seif El-Yazal, M.M. Rady, Integrated effect of potassium humate and $\alpha$-tocopherol applications on soil characteristics and performance of Phaseolus vulgaris plants grown on a saline soil, Archives of Agronomy and Soil Science. 63 (2017) 1556-1571.

[14] . Yasar, S. Kusvuran, S. Ellialtioğlu, Determination of anti-oxidant activities in some melon (Cucumis melo L.) varieties and cultivars under salt stress, The Journal of Horticultural Science and Biotechnology. 81 (2006) 627-630.

[15] B. Yildirim, F. Yaser, T. Ozpay, D. TurkOzu, O. Terziolu, A. Tamkoc, Variations in response to salt stress among field pea genotypes (Pisum sativum sp. arvense L.), Journal of Animal and Veterinary Advances. 7 (2008) 907-910.

[16] M. Mishra, P.K. Mishra, U. Kumar, V. Prakash, NaCl phytotoxicity induces oxidative stress and response of antioxidant system in Cicer arietinum L. cv. Abrodbi, Botany Research International. 2 (2009) 74-82.

[17] S.A. Orabi, B.B. Mekki, F.A. Sharara, Alleviation of adverse effects of salt stress on faba bean (Vicia faba L.) plants by exogenous application of salicylic acid, World Applied Sciences Journal. 27 (2013) 418-427.

[18] T.A. Cuin, Y. Tian, S.A. Betts, R. Chalmandrier, S. Shabala, Ionic relations and osmotic adjustment in durum and bread wheat under saline conditions, Functional Plant Biology. 36 (2009) 1110-1119.

[19] Y. Hu, U. Schmidhalter, Drought and salinity: a comparison of their effects on the mineral nutrition of plants, Journal of Plant Nutrition and Soil Science. 168 (2005) 541-549.

[20] C.P. Vance, C. Uhde-Stone, D.L. Allan, Phosphorus acquisition and use: critical adaptations by plants for securing a nonrenewable resource, New Phytologist. 157 (2003) 423-447.

[21] A. Cerda, F.T. Bingham, G. Hoffman, Interactive effect of salinity and phosphorus on sesame, Soil Science Society of America Journal. 41 (1977) 915-918.

[22] B. L'taief, S. Bouaziz, Z. Mainassara, H. Ralf, C. Molina, S. Beebe, P. Winter, G. Kahl, J.J. Drevon, M. Lachaâl, Genotypic variability for tolerance to salinity and phosphorus deficiency among N2-dependent recombinant inbred lines of Common Bean (Phaseolus vulgaris), African Journal of Microbiology Research. 6 (2012) 4205-4213.

[23] A.I. Page, R.H. Miller, D.R. Keeney, Methods of Soil Analysis. Part 2: Chemical and Microbiological Properties. 2nd Ed (1982). American Society of Agronomy, Madison, Wisconsin, USA.

[24] A. Klute, Methods of Soil Analysis. Part 1: Physical and Mineralogical Methods. 2nd Ed., Wisconsin, USA: American Society of Agronomy Madison, 1986.

[25] W.C. Dahnke, D.A. Whitney, Measurement of soil salinity. In: Dahnke, W. C. (Ed.). Recommended Chemical Soil Test Procedures for the North Central Region, North Central Regional Publication 221, North Dakota Agricultural Experiment Station Bulletin. 499 (1988) $32-34$.

[26] A.A.A. Mekded, M.M. Rady, Response of Beta vulgaris L. to nitrogen and micronutrients in dry environment, Plant, Soil and Environment. 62(1) (2016) 23-29.

[27] R.G. Allen, L.S. Pereira, D. Raes, M. Smith, Crop evapotranspiration guidelines for computing crop water requirements, Irrigation and Drainage. Paper 56 (1998), FAO, Rome, pp. 300.

[28] M.T. Abdelhamid, M.M. Rady, A.Sh. Osman, M.S. Abdalla, Exogenous application of proline alleviates salt induced oxidative stress in Phaseolus vulgaris L. plants, The Journal of Horticultural Science \& Biotechnology. 88 (2013) 439-446. 
[29] A.R. Welburn, H. Lichtenthaler, Formulae and program to determine total carotenoids and chlorophylls a and b leaf extracts in different solvents, in: C. Sybesma (Ed.), Advances in photosynthesis research. 2 (1984) 9-12.

[30] K. Maxwell, G.N. Johnson, Chlorophyll fluorescence-a practical guide, Journal of Experimental Botany. 51 (2000) 659-668.

[31] A.J. Clark, W. Landolt, J.B. Bucher, R.J. Strasser, Beech (Fagus sylvatica) response to ozone exposure assessed with a chlorophyll a fluorescence performance index, Environmental Pollution. 109 (2000) 501-507.

[32] A.R. Hafez, D.S. Mikkelsen, Colorimetric determination of nitrogen for evaluating the nutritional status of rice, Communications in Soil Science and Plant Analysis. 12 (1981) 6169.

[33] C.S. Piper, Soil and plant analysis, Inter. Sci. Inc. Nc. USA (1947).

[34] M.L. Jackson, Soil Chemical Analysis. Prentice Hall of India Pvt. Ltd, New Delhi, India, 1967, pp. 144-197, 326-338.

[35] H.D. Chapman, P.F. Pratt, Methods of Analysis for Soil, Plants and Water. University of California, Division of Agricultural Science, Berkeley, CA, USA, 1961, pp. 56-63.

[36] M. Lachica, A. Aguilar, J. Yanez, Analisis Foliar. Métodos Utilizados enla EstaciLn Experimental del Zaidin, Anales de Edafologia y Agrobiologia, 1973, pp. 1033-1047.

[37] K.A. Gomez, A.A. Gomez, Statistical Analysis Procedures for Agricultural Research. John Wiley and Sons, New York, NY, USA, 1984, pp: 25-30.

[38] M.M. Rady, B.C. Varma, S.M. Howladar, Common bean (Phaseolus vulgaris L.) seedlings overcome $\mathrm{NaCl}$ stress as a result of presoaking in Moringa oleifera leaf extract, Scientia Horticulturae. 162 (2013) 63-70.

[39] W.M. Semida, R.S. Taha, M.T. Abdelhamid, M.M. Rady, Foliar-applied $\alpha$-tocopherol enhances salt-tolerance in Vicia faba L. plants grown under saline conditions, South African Journal of Botany. 95 (2014) 24-31.

[40] W.M. Semida, T.A. Abd El-Mageed, S.M. Howladar, M.M. Rady, Foliar-applied $\alpha-$ tocopherol enhances salt-tolerance in onion plants by improving antioxidant defence system, Australian Journal of Crop Science. 10(7) (2016) 1835-2707.

[41] L. Xiong, J.K. Zhu, Molecular and genetic aspects of plant responses to osmotic stress, Plant, Cell \& Environment. 25 (2002) 131-139.

[42] J.K. Zhu, Plant salt tolerance, Trends in Plant Science. 6 (2001) 66-71.

[43] V. Parida, A.B. Das, Salt tolerance and salinity effects on plants: a review, Ecotoxicology and Environmental Safety. 60 (2005) 324-349.

[44] M. Juan, R.M. Rivero, L. Romero, J.M. Ruiz, Evaluation of some nutritional and biochemical indicators in selecting salt-resistant tomato cultivars, Environmental and Experimental Botany. 54 (2005) 193-201.

[45] R.K. Sariam, K.V. Rao, G.C. Srivastava, Differential response of wheat genotypes to long term salinity stress in relation to oxidative stress, antioxidant activity and osmolyte concentration, Plant Science. 163 (2002) 1037-1046.

[46] J. Cuartero, R. Fernández-Mũnoz, Tomato and salinity, Scientia Horticulturae. 78 (1999) 83125.

[47] E. Cicek, F. Yilmaz, M. Yilmaz, Effect of N and NPK fertilizers on early field performance of narrow-leaved ash, Fraxinus angustifolia, Journal of Environmental Biology. 31(1-2) (2010) 109-114. PMID: 20648820.

[48] E.A. Waraich, Z. Ahmad, R. Ahmad, Saifullah, M.Y. Ashraf, Foliar applied phosphorous enhanced growth, chlorophyll contents, gas exchange attributes and PUE in wheat (Triticum aestivum L.), Journal of Plant Nutrition. 38(12) (2015) 1929-1943.

[49] A.Sh. Osman, M.M. Rady, Ameliorative effects of sulphur and humic acid on the growth, antioxidant levels and yields of pea (Pisum sativum L.) plants grown in reclaimed saline soil, The Journal of Horticultural Science and Biotechnology. 87(6) (2012) 626-632. 
[50] S.T. Pandey, P. Singh, P. Pandey, Site specific nutrient management for Withania somnifera at subtropical belt of Uttaranchal, International Journal of Agricultural Science. 2 (2006) 626628.

[51] F. Zapata, A.R. Zaharah, Phosphate availability from phosphate rock and sewage sludge as influenced by addition of water soluble phosphate fertilizers, Nutrient Cycling in Agroecosystems. 63 (2002) 43-48.

[52] E. Epstein, A.J. Bloom, Mineral nutrition of plants: Principles and perspectives( Second Edition). Sunderland, MA: Sinauer Associates, Inc.; 2004.

[53] S.M.S. Hudai, M. Sujauddin, S. Shafinat, M.S. Uddin, Effects of phosphorus and potassium addition on growth and nodulation of Dalbergia sissoo in the nursery, Journal of Forest Research. 18(4) (2007) 279-282.

[54] R.K. Verma, P.K. Khatri, M. Bagde, H.D. Pathak, N.G. Totet, Effect of biofertilizer and phosphorous on growth of Dalbergia sissoo, Indian Journal of Forestry. 19(3) (1996) 244-246.

[55] I. Cakmak, C. Hengeler, H. Marschner, Partitioning of shoot and root dry matter and carbohydrates in bean plants suffering from phosphorus, potassium and magnesium deficiency, Journal of Experimental Botany. 45(9) (1994) 1245-1250.

[56] M.G. Dawood, M.T. Abdelhamid, U. Schmidhalter, Potassium fertiliser enhances the salttolerance of common bean (Phaseolus vulgaris L.), The Journal of Horticultural Science and Biotechnology. 89 (2014) 185-192.

[57] M.M. Rady, M.Sh. Sadak, S.R. El-Lethy, E.M. Abd Elhamid, M.T. Abdelhamid, M.T. Exogenous $\alpha$-tocopherol has a beneficial effect on Glycine max (L.) plants irrigated with diluted sea water, The Journal of Horticultural Science and Biotechnology. 90(2) (2015) 195202.

[58] L.I. Rong-hua, G.U.O. Pei-guo, M. Baum, S. Grando, S. Ceccarelli, Evaluation of chlorophyll content and fluorescence parameters as indicators of drought tolerance in barley, Agricultural Sciences in China. 5 (2006) 751-757.

[59] M.T. Abdelhamid, M. Shokr, M.A. Bekheta, Growth, root characteristics, and leaf nutrients accumulation of four faba bean (Vicia faba L.) cultivars differing in their broomrape tolerance and the soil properties in relation to salinity, Communications in Soil Science and Plant Analysis. 41 (2010) 2713-2728.

[60] M.G. Dawood, H.A.A. Taie, R.M.A. Nassar, M.T. Abdelhamid, U. Schmidhalter, The changes induced in the physiological, biochemical and anatomical structure of Vicia faba by the exogenous application of proline under seawater stress, South African Journal of Botany. 93 (2014) 54-63.

[61] C.S.T. Daughtry, C.L. Walthall, M.S. Kim, E. Brown de Colstoun, J.E. McMurtrey, Estimating corn leaf chlorophyll concentration from leaf and canopy reflectance, Remote Sensing of Environment. 74(2) (2000) 229-239.

[62] B. Bojovic, J. Stojanovic, Some wheat leaf characteristics in dependence of fertilization, Kragujevac Journal of Science. 28 (2006) 139-146.

[63] Shubhra, J. Dayal, C.L. Goswami, R. Munjal, Influence of phosphorus application on water relations, biochemical parameters and gum content in cluster bean under water deficit, Biologia Plantarum. 48(3) (2004) 445-448.

[64] S. Dutt, S.D. Sharma, P. Kumar, Inoculation of apricot seedlings with indigenous arbuscular mycorrhizal fungi in optimum phosphorus fertilization for quality growth attributes, Journal of Plant Nutrition. 36(1) (2013) 15-31.

[65] A. Celekli, M. Yavuzatmaca, H. Bozkurt, Modeling of biomass production by Spirulina platensis as function of phosphate concentrations and $\mathrm{pH}$ regimes, Bioresource Technology. 100(14) (2009) 3625-3629.

[66] X.L. Liang, Y.C. Lin, H. Nian, L.X. Xie, The effect of low phosphorus stress on main physiological traits of different maize genotypes, Acta Agronomica Sinica. 31(5) (2005) 667669. 
[67] K.H. Kiarostami, R. Mohseni, A. Saboora, Biochemical changes of Rosmarinus officinalis under salt stress, Journal of Stress Physiology and Biochemistry. 6 (2010) 114-122.

[68] M. Ashraf, P.J.C. Harris, Potential biochemical indicators of salinity tolerance in plants, Plant Science. 166 (2004) 3-16.

[69] M.A. Gharsa, E. Parre, A. Debez, M. Bordenava, L. Richard, L. Leport, A. Bouchereau, A. Savoure, C. Abdelly, Comparative salt tolerance analysis between Arabidopsis thaliana and Thellungiella halophila, with special emphasis on $\mathrm{K}^{+} / \mathrm{Na}^{+}$selectivity and proline accumulation, Journal of Plant Physiology. 165 (2008) 588-599.

[70] H. Marschner, Mineral Nutrition of Higher Plants. $2^{\text {nd }}$ Ed. New York, NY, USA: Academic Press Publication, 1995, pp. 559-579.

[71] Z. Noreen, M. Ashraf, N.A. Akram, Salt-induced regulation of some key antioxidant enzymes and physio-biochemical phenomena in five diverse cultivars of turnip (Brassica rapa L.), Journal of Agronomy and Crop Science. 196 (2010) 273-285.

[72] J.M. Lenis, M. Ellersieck, D.G. Blevins, D.A. Sleper, H.T. Nguyen, D. Dunn, J.D. Lee, J.G. Shannon, Differences in ion accumulation and salt tolerance among glycine accessions, Journal of Agronomy and Crop Science. 197 (2011) 302-310.

[73] R. Munns, M. Tester, Mechanisms of salinity tolerance, Annual Review of Plant Biology. 59 (2008) 651-681.

[74] P.J.C. Kuiper, Functioning of plant cell membrane under saline conditions: membrane lipid composition and ATPases. In: R.C. Staples, and G.H. Toenniessen, eds. Salinity Tolerance in Plant: Strategies for Crop Improvement, John Wiley and Sons, Inc., New York, NY, USA, 1984, pp. 77-91.

[75] R.S. Malik, A.P. Gupta, S. Haneklaus, N. El-Bassam, Role of phosphorus (P) in inducing salt tolerance in sunflower, Landbauforschung Völkenrode. 49 (1999) 169-176.

[76] S.R. Grattan, C.M. Grieve, Mineral nutrient acquision and response by plants in saline environment. In: M. Pessarakali, ed. Handbook of Plant and Crop Stress, Marcel Dekker, Inc., New York, NY, USA, 1993, pp. 203-266. 